\title{
Experimental Investigation of the Hydroxy Gas Generation as a Clean Energy Source for Spark Ignition Engine Operation Using Different Electrolytes
}

\author{
Yousef A. Sharif', Saad S. Jasim², Rafeq A. Khalefa ${ }^{3}$, Shivan J. Taher ${ }^{4}$ \\ ${ }^{1}$ Department of Petroleum Equipment, Erbil Technology Institute, Erbil Polytechnic University, Erbil, Kurdistan Region, Iraq, ${ }^{2}$ Department of \\ Chemistry, College of Education for Pure Sciences, University of Kirkuk, Kirkuk, Iraq, ${ }^{3}$ Department of Fuel and Energy, Technical College, \\ Northern Technical University, Kirkuk, Iraq, ${ }^{4}$ Department of Pharmacy, Erbil Medical Institute, Erbil Polytechnic University, Erbil, Kurdistan \\ Region, Iraq
}

\section{*Corresponding author: Yousef A. Sharif, Department of Petroleum Equipment, Erbil Technology Institute, Erbil Polytechnic University, Erbil, Kurdistan Region, Iraq. E-mail: yousef.luki@gmail. com}

\section{Received: 15 May 2020}

Accepted: 09 September 2020

Published: 30 June 2021

\section{DOI}

10.25156/pty.v11n1y2021.pp16-21

\section{A B S T R A C T}

The main objective of this research is to generate the hydrogen gas as a fuel and part of hydroxy gas ( $\mathrm{HHO})$ from the drinking water $\left(\mathrm{H}_{2} \mathrm{O}\right)$ using electrolyzing method with a different electrolytes such as sodium hydroxide $(\mathrm{NaOH})$, sodium carbonate $\left(\mathrm{Na}_{2} \mathrm{CO}_{3}\right)$, and Vinegar in $\mathrm{HHO}$ generator for best results, the practical examinations were done by a generator that designed and built for this purpose using plate electrodes, with a rechargeable 12-volt battery and the produced gas was measured at each case and used as a fuel for operating a small single-cylinder spark-ignition engine (Honda G 200) with taking into account the safety precautions. The results show that increasing the ratio of $(\mathrm{NaOH})$ grams/liter of $\mathrm{H}_{2} \mathrm{O}$ increases the gas production, while the other two electrolytes $\left(\mathrm{Na}_{2} \mathrm{CO}_{3}\right.$ and vinegar) are not effecting too much, and using the mixing procedure $(\%)$ of the electrolytes $\left(\mathrm{NaOH}\right.$ with $\left.\mathrm{Na}_{2} \mathrm{CO}_{3}\right)$ and $\left(\mathrm{Na}_{2} \mathrm{CO}_{3}\right.$ with Vinegar), it is observed that the $\mathrm{HHO}$ generation noticeable increases with increasing the mixing ratio of the first mixture and not too much with the second.

Keywords: Hydroxy gas generation; Electrolytes; Hydroxy gas fuel; Clean energy source; Alternative fuels

\section{INTRODUCTION}

The major interested fields nowadays are energy sources and air pollution and great efforts were conducted by researchers and engineers to promoting this fields using different methods, techniques, where the focus was on alternative fuels for operating engines, power plants with fewer pollutants such as waterfall, solar energy, and hydrogen $\left(\mathrm{H}_{2}\right)$ generation.

$\mathrm{H}_{2}$ generation is highly regarded by scientists and specialists due to high energy content and less pollution, the generation process was done by decomposition of water $\left(\mathrm{H}_{2} \mathrm{O}\right)$ into oxygen $\left(\mathrm{O}_{2}\right)$ and $\mathrm{H}_{2}$ using the electrolysis method which requires a potential difference of (1.23) volts to split $\mathrm{O}_{2}$. In 1989 an electrostatic machine carried out using gold electrodes in a Leyden jar with $\mathrm{H}_{2} \mathrm{O}$ (Sierens and Rosseel, 1995), this method was developed as an industrial synthesis of $\left(\mathrm{H}_{2}\right)$ and $\left(\mathrm{O}_{2}\right)$ (Sierens and Rosseel, 1998). The connecting of electric power to two electrodes (metal plates) which are placed in the $\mathrm{H}_{2} \mathrm{O}, \mathrm{H}_{2}$ will appear at the cathode and $\mathrm{O}_{2}$ will appear at the anode (Shinnar, 2003). The ignition products of hydroxy $(\mathrm{HHO})$ gas are $\mathrm{H}_{2} \mathrm{O}$ vapor and energy release, a common application of $\mathrm{HHO}$ is in torches for the processing of refractory materials and the recent application of $\mathrm{HHO}$ is in running the engines on the $\mathrm{H}_{2} \mathrm{O}$ (Schulte et al., 2004).

Electrolysis of pure $\mathrm{H}_{2} \mathrm{O}$ requires excess energy and without the excess energy, the electrolysis of pure $\mathrm{H}_{2} \mathrm{O}$ occurs very slowly or not at all. The efficiency of electrolysis increases with the addition of an electrolyte (such as salt, acid, or a base). The electricity used for electrolysis is generated from fossil fuels, then carbon dioxide would be emitted in support of the electrolysis process, and the advantage of using $\mathrm{H}_{2}$ as a fuel would be lost. However, if the electricity is produced by solar cells, then there will be no pollutants released by the electrolysis process (Santilli, 2006). The process by which used for generating $\mathrm{H}_{2}$ and $\mathrm{O}_{2}$ from $\mathrm{H}_{2} \mathrm{O}$ called electrolysis. The electrolytes used to make the $\mathrm{H}_{2} \mathrm{O}$ more conductive (Momirlan and Veziroglu, 2002).

Electricity $+2 \mathrm{H}_{2} \mathrm{O} \longrightarrow \mathrm{O}_{2}+2 \mathrm{H}_{2} \quad$ Eq.(1)

$\mathrm{HHO}$ gas has a number of distinct features that distinguish it from other fuels (from $\mathrm{H}_{2} \mathrm{O}$ vapor, and brown gas) and 
other variants. Where HHO Gas proves to be odorless, colorless and lighter than air and when it burns the instantaneous temperature reaches over 10,000 F, under which virtually all substances on Earth can be sublimated (Dunn, 2002). $\mathrm{H}_{2}$ is a clean energy source and gives power about 3 times more than a conventional carbon fuel due to these reasons scientists chose $\mathrm{H}_{2}$ to power the space mission rockets. There is no other fuel more efficient than $\mathrm{H}_{2}$. When burning $\mathrm{H}_{2}$, there is no other byproduct (e.g., $\mathrm{NO}_{\text {) }}$ coming out of the car exhausts as well as in burning carbon-based fuels. The result of burning $\mathrm{H}_{2}$ in exhaust is the vapor of $\mathrm{H}_{2} \mathrm{O}$ (pure $\mathrm{H}_{2} \mathrm{O}$ ). There is no other emitted impurity but clean $\mathrm{H}_{2} \mathrm{O}$ in the gaseous phase (Barreto et al., 2003). An electrolyte is any substance containing free ions that make the substance electrically conductive. When table salt, $\mathrm{NaCl}$, is placed in $\mathrm{H}_{2} \mathrm{O}$, the salt (a solid) dissolves into its component elements, according to the dissociation reaction (Appleby, 1994).

$$
\mathrm{NaCl}_{(\mathrm{s})} \longrightarrow \mathrm{Na}_{(\text {aq) }}^{+}+\mathrm{Cl}_{(\text {(aq) }}^{-} \text {Equ.(2) }
$$

The main goal of this research is producing $\mathrm{H}_{2}$ by analyzing the drinking $\mathrm{H}_{2} \mathrm{O}$ and using it for engine operating as a fuel, to reduce air pollution and making life healthy by solving the problems of fuel when it is used as an energy source for machines. The burning process of hydrocarbon fuels (gasoline, gas oil, etc.) leaves harmful (toxic) products such as $\mathrm{CO}_{2}, \mathrm{CO}$, and $\mathrm{NO}_{\mathrm{x}}$ coming out of the car. So using a new type of energy as a fuel source, those problems that be affected by people can be solved using HHO gas as fuel source. It would have completely eliminated global warming as it relates to the burning of fuel. This new technology produces infinitely more power than it uses because its fuel is $\mathrm{H}_{2} \mathrm{O}$ (Ilhak et al., 2019).

\section{Basic Principles of Generator Design}

The generator is designed in such a way that the maximum output energy achieved with minimum input, the input energy is supplied by the car battery in the form of direct current. Hence, in essence, a direct current is passed through two bare plats which are dipped in a bucket of $\mathrm{H}_{2} \mathrm{O}$, to which a small electrolyte $(\mathrm{NaOH}$ was used in this research) is added. The electrical current requirement is in the range of 1.5 to 2 volts DC. This produces HHO in a very small quantity. This is the basic principle of an $\mathrm{HHO}$ generator (EL-Kassaby et al., 2016).

\section{Types of HHO Generator}

The HHO generator is the device which is primarily involved with the production of HHO gas and there are two main types of the $\mathrm{H}_{2}$ generator the first type is a "Dry Cell" in which each $\mathrm{H}_{2} \mathrm{O}$ compartment is sealed so that $\mathrm{H}_{2} \mathrm{O}$ cannot leak from compartment to compartment (cell to cell). The bottom edges of the plates are sealed off in a manner that keeps the $\mathrm{H}_{2} \mathrm{O}$ from touching them [Figure 1]. If the chamber does not keep the edges of the plates dry, it is not a dry cell (Bacon, 1969). The second type is (Wet Cell) in which the cells are comprised in an electrolyte-filled container and the electrodes are either fully or partially submerged as in [Figure 2]. They are generally made of stainless steel plates, wound wire, bolts or various other materials. The main feature of a Wet Cell is that it is self-contained. The advantages of this type are that they are easy to build and have fewer components (Badwal et al., 1999). Although few Wet Cells produce more than $(1.5 \mathrm{lt} / \mathrm{min})$, they can be chained together to increase their overall output.

\section{Configurations of Fuel Cell Construction}

The construction and designing process of a fuel cell are beginning with the information must be taken into account such as configuration type low voltage/high amperage (LVHA) configuration, or high voltage/low amperage (HVLA) and determination the desired Plate Gap Voltage,

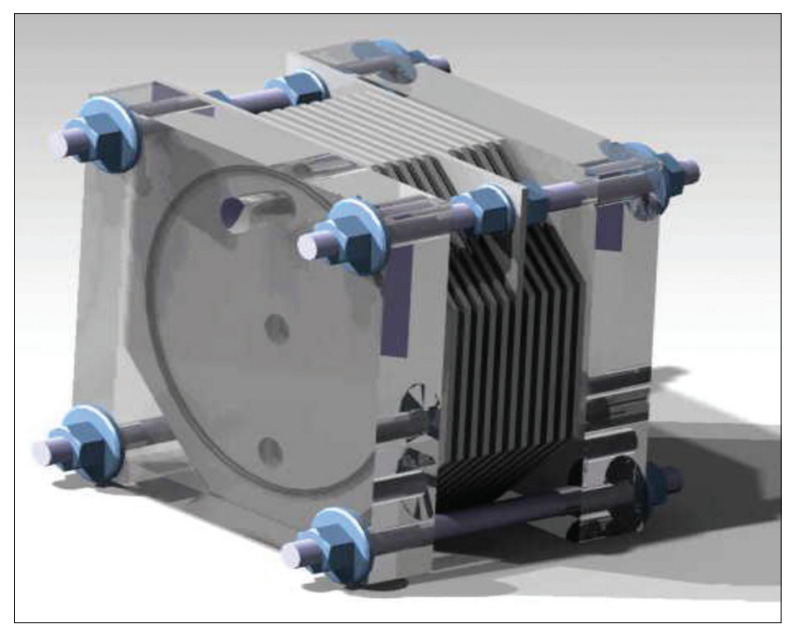

Figure 1: Dry cell

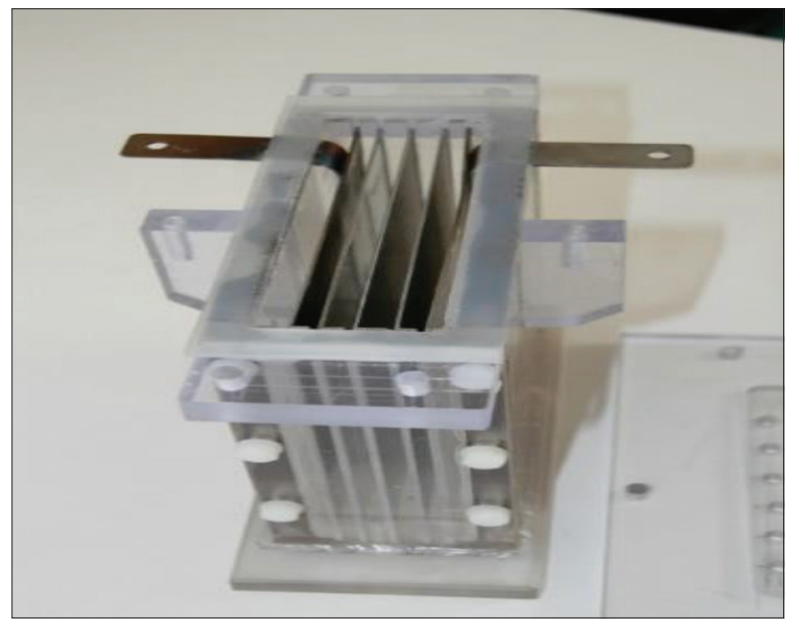

Figure 2: Wet cell 
verifying the supply voltage with a good electrical meter (13.6 volts are typical), (automotive battery often used), and the number of plates in each cell can be determined by using:

$$
\text { Number of plates }=\mathrm{N}=\mathrm{VS} / \mathrm{PGV}
$$

Where

VS = Supply Voltage and PGV = Plate Gap Voltage

The single-cell configuration would be as follows: $+\mathrm{N} N$ N N -

for more than one cell the following configurations can be applied:

2 cells: (- NNNN + NNNN -), and 3 cells: (- NNNN + $\mathrm{NNNN}-\mathrm{NNNN}+$ )

Where HHO production depends on the total amount of surface area within the total cell, the more surface area the more HHO can be produced (Barclay, 2002). And the HVLA configuration needs to verify the supply voltage with a good electrical meter. Direct Current needed for this purpose. HHO production depends a great deal on the surface area of the electrodes or when the cell was large, even a little amperage can produce large quantities of HHO (Hoogers, 2002).

\section{MATERIALS AND CONSTRUCTION STEPS}

In this work, the HHO gas generator was designed, manufactured and tested where the dry cell and HVLA configuration type was chosen, and the construction steps beginning with preparing electrodes, where electrode is a conductor such as metal wire or plate submerged in an electrolyte to allow electrons (electrical current) to pass throws the electrolyte. For this reason, the aluminum plates are chosen and prepared [Figure 3]. The surface must be clean; if it is not, gas production will be restricted. Dirt blocks the surface area; so does oil; even oil from human fingers that got there while the plates were handled the Vinegar usually gets the job done. If Acetone was available, fingernail polish remover, it works too; evaporates extremely fast (Larminie et al., 2003).

Dry Cells are considered "dry" because the electrodes are separated from the reservoir. The electrolyte is contained between the electrodes, rather than around them. This design greatly improves efficiency by reducing paralytic current losses that occur at the edges of the electrodes. Typically, a Dry Cell is usually made of stainless steel electrodes separated by gaskets. The gaskets separate each electrode which has holes to allow the electrolyte level between each electrode to equalize. Plates at either end hold all the electrodes and gaskets together with bolts. The alignment of gasket [Figure 4] is the importance of making absolutely sure that the electrode plates are perfectly aligned left, right, up, and down. It needs to be as close to "level" with each other as it can be got. If the Dry Cell uses gaskets between plates to create a self-contained, it is very important to make sure each gasket is aligned the same and each bolt torque is the same pressure.

When the electrodes are energized, HHO is produced and escapes out a hole placed at the top of one of the endplates. In general, the electrolyte levels stay below the top of the plates, and the HHO is collected at the top of the container. Dry Cells are highly efficient and tend to produce larger quantities of $\mathrm{HHO}$ with less energy.

If the Dry Cell uses gaskets to create and separate cell chambers, the plates will need a hole for the gases to get out of the chamber. As gases are made, they rise to the top of the chamber, looking for a way out. If the hole is one half of an inch below the top, the gases will go right on by it and accumulate at the top of the gasket. Nothing gets out the hole until enough gas collects at the top and

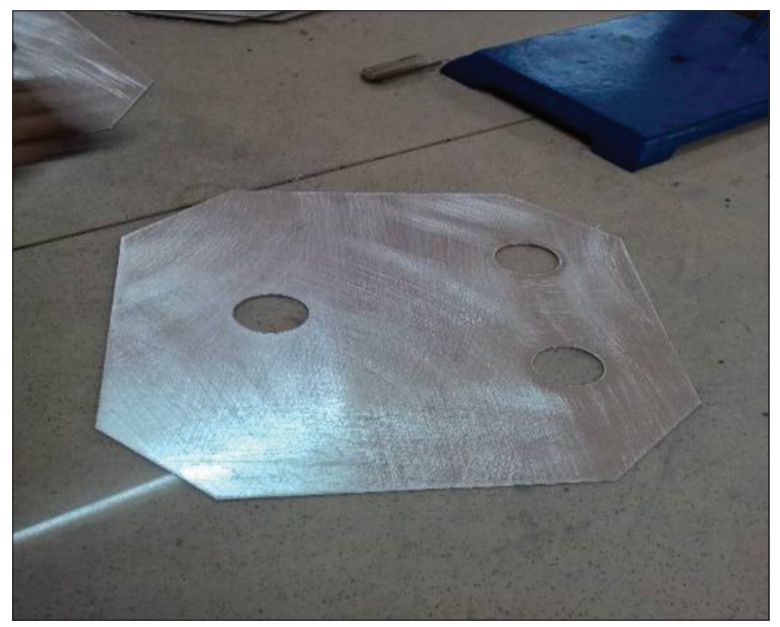

Figure 3: Aluminum Electrode

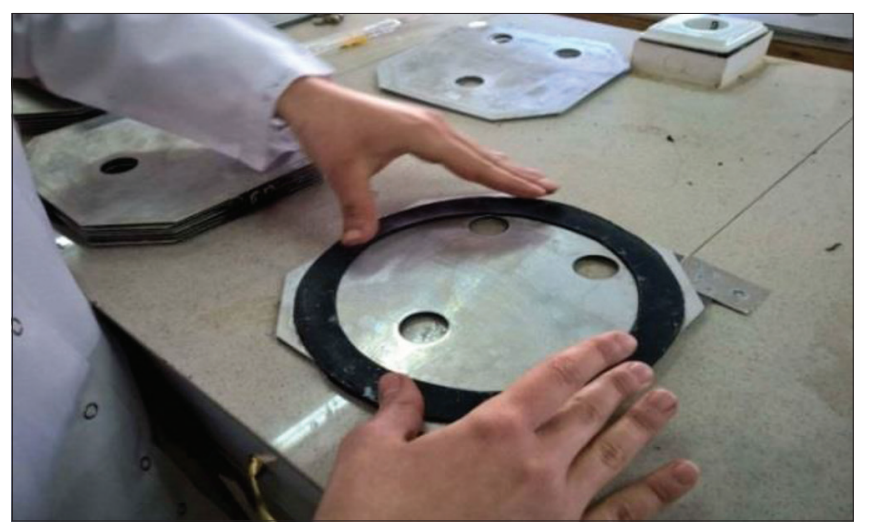

Figure 4: Gasket alignment 
lowers the $\mathrm{H}_{2} \mathrm{O}$ level to that of the hole. Place the holes closer to the top of the gasket. Gaskets take up valuable plate surface area. Use them wisely, and likewise, place the outlet holes closer to the top [Figure 5].

The $\mathrm{H}_{2} \mathrm{O}$ chamber must be full of $\mathrm{H}_{2} \mathrm{O}$ during the operation, for this aim the $\mathrm{H}_{2} \mathrm{O}$ inlet port must be provided to compensate the shortage of the $\mathrm{H}_{2} \mathrm{O}$ in the $\mathrm{H}_{2} \mathrm{O}$ chamber as in Figure 6. For most dry cell designs, that means putting another hole in the plates; taking away from surface area and creating places for electrical current to jump. Furthermore, before you make that hole, it is important to realize that it will affect $\mathrm{H}_{2} \mathrm{O}$ circulation. If the hole placed too high, $\mathrm{H}_{2} \mathrm{O}$ will not circulate below the hole. That means it could be creating hot spots. As the bubbles rise to the top of the chamber, it creates an upward current in the $\mathrm{H}_{2} \mathrm{O}$.

The current is the force that pulls cooler $\mathrm{H}_{2} \mathrm{O}$ into the chamber, from the Bubbler, or $\mathrm{H}_{2} \mathrm{O}$ Reservoir. Some experts use only one hole for their plate design (One hole for gases to escape through and for $\mathrm{H}_{2} \mathrm{O}$ refill).

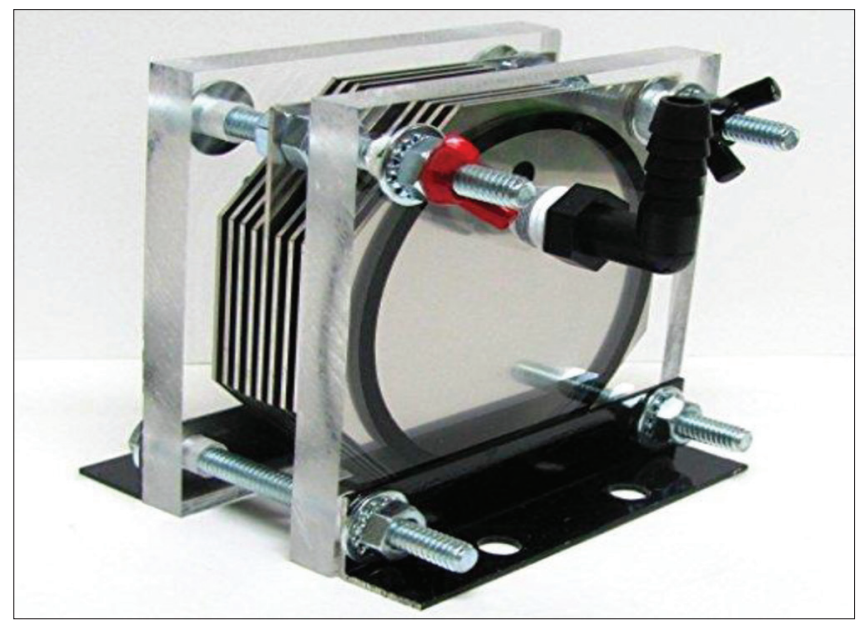

Figure 5: Gas outlet port

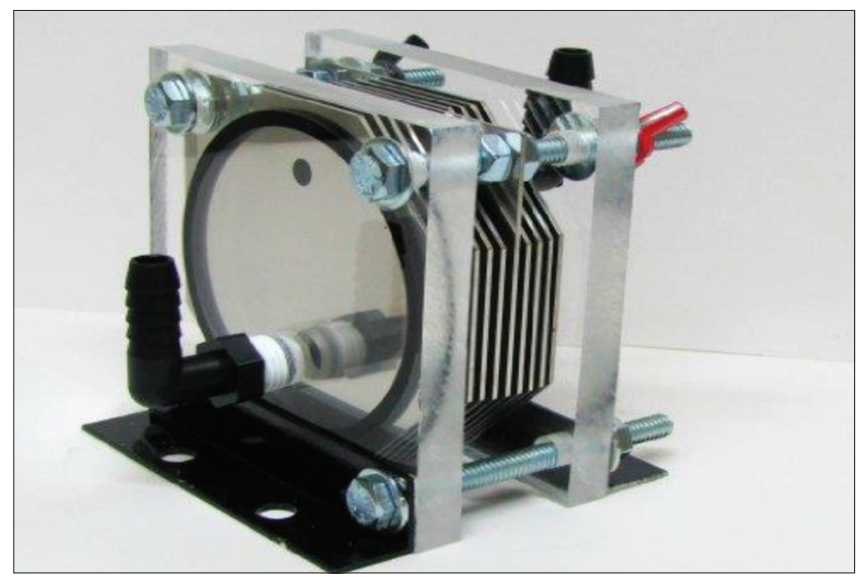

Figure 6: Water inlet port
According to the previous conclusions the 42 electrolyze aluminum plates are about $0.7 \mathrm{~mm}$ thick $200 \mathrm{~mm} \times$ $200 \mathrm{~mm}$ of aluminum alloy (7075-T6). A $20 \mathrm{~mm}$ gas vent hole is drilled in each plate, the electrolyte level is always about $160 \mathrm{~mm}$ below the gas vent hole. There are $20 \mathrm{~mm}$ diameter liquid level equalization holes drilled in the bottom center of each plate. Staggering and using small holes minimize any efficiency loss due to current leakage between cells, but makes electrolyte refilling and level equalization significantly easier. The two endplates have a small SS piece welded for electrical contact. The method to increase plate area exists as well, (41) spacers were cut out of $2 \mathrm{~mm}$ thick of hard rubber. The first rubber ring is placed on the plexiglass and silicone put on, then by this series the construction was done (plate-ring-platering-plate) to the last ring, then the other plexiglass was added and tied with the 12 bolts and pressurized to be $\mathrm{H}_{2} \mathrm{O}$ tied, then the gas and $\mathrm{H}_{2} \mathrm{O}$ ports were added. Due to the nature of the produced gases and to prevent the explosions accident it is very necessary to take account of the safety factors by preparing a non-return valve or by providing so-called bubbler [Figure 7]. The bubbler is absolutely essential to prevent backfires from blowing up the electrolyzer. The bubbler may be filled with slightly acidic $\mathrm{H}_{2} \mathrm{O}$ (use vinegar) to neutralize any residual $\mathrm{NaOH}$ vapors in the output gas.

After manufacturing the $\mathrm{HHO}$ generator and preparing the necessary parts the assembling process of the system accomplished [Figure 8], three types of electrolytes are tested which are $(\mathrm{NaOH}$ which has purity $\geq 97.0 \%$, sodium carbonate $\left(\mathrm{Na}_{2} \mathrm{CO}_{3}\right)$ with purity $99.5 \%$ from Sigma-Aldrich) and vinegar in aqueous solution by $\% \mathrm{gm} / \mathrm{L}$ concentration for each material or mixture, Zahdi date vinegar had been used which contains up to $6.62 \pm 0.15 \%$ acetic acid $\mathrm{CH}_{3} \mathrm{COOH}$ (Matloob, 2014), and the generated HHO gas was introduced to the air stream just before entering

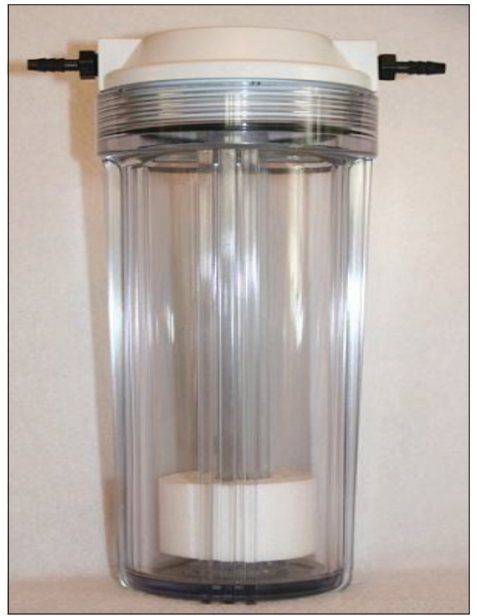

Figure 7: Bubbler 
the carburetor of a single-cylinder 4-stroke spark ignition engine type (Honda G 200 engine).

Figure 9 clarifies the schematic diagram of the HHO generator system. Whereas part (a) simplifies the system with pure water as fuel since $\mathrm{NaOH}$ is not entering the engine's air inlet. On the other side, part (b) shows the water recycling to the $\mathrm{HHO}$ generator.

\section{RESULTS AND DISCUSSION}

The electrode plates after the electrolyzer had been used for some time. The chemical reactions occurring in the electrolyzer have slightly darkened the electrolyte. The use of (316 SS) electrodes would probably have prevented this (Abdallah et al., 2017).

In this work, Fuel Cell for HHO gas generation was designed, manufactured and tested. The generated HHO gas was introduced to the air stream just before entering the carburetor of a Honda G 200 engine. The following results can be drawn.

It was noticed from [Figure 10] that the gas production increases with the increase in the electrolyte weight, by the use of different available electrolytes, it was observed

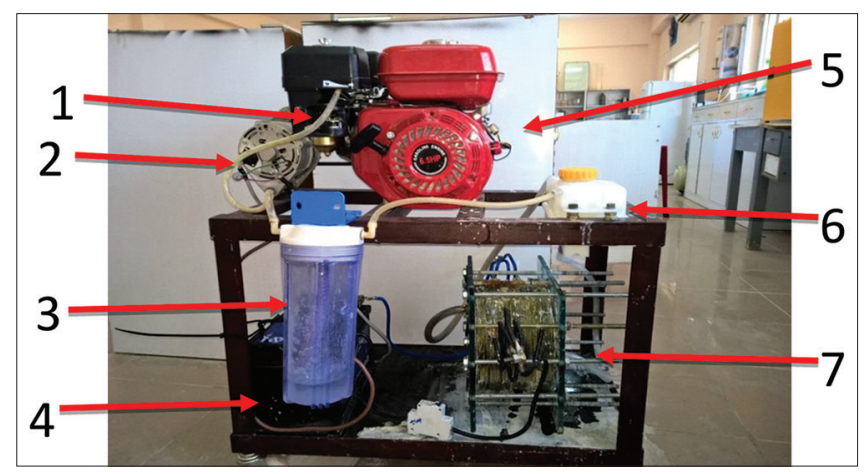

Figure 8: The hydroxy $(\mathrm{HHO})$ generator system, with the engine used in the research, (1) HHO Gas, (2) Alternator (recharges the power source). (3) Bubbler (Flash Back arrestor). (4) Battery (Power source). (5) Engine (Honda G 200 engine). (6) Storage Tank $\left(\mathrm{H}_{2} \mathrm{O}+\mathrm{NaOH}\right)$. (7) Fuel Cell

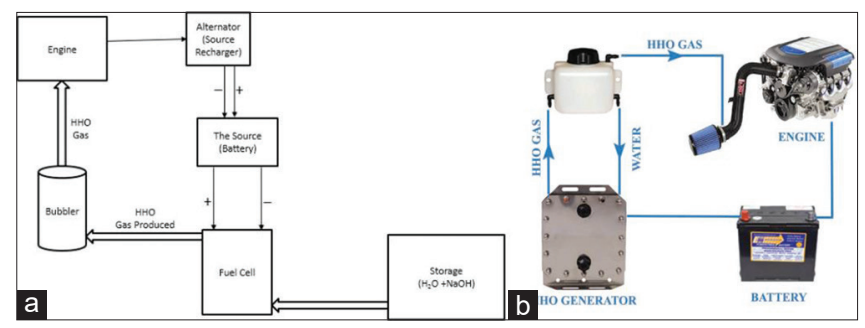

Figure 9: (a and b) Schematic diagram of hydroxy generator system Electrolyte (gm/L water) that sodium hydroxide $(\mathrm{NaOH})$ is the best electrolyte to be used as it gives a big jump in gas production between (40 and $50 \mathrm{~g}$ ) (10 g) made a big difference, therefore, the efficiency of HHO production increased by nearly $(77 \%)$, it was also observed that the production of $\mathrm{HHO}$ gas is nearly the same if Baking soda and vinegar were used, while between the same amounts of them $(40-50 \mathrm{~g})$ the efficiency of gas production increased only (35\%). At (50 g) of $\mathrm{NaOH}$ the fuel gas production is $(6.5 \mathrm{~L} / \mathrm{min})$, while at the same amounts of baking soda and vinegar severally its production is about $(3.55 \mathrm{~L} / \mathrm{min})$, that means nearly $(46 \%)$ more efficiency of gas production in the case of using $\mathrm{NaOH}$ relative to using baking soda or vinegar.

It was noticed from Figure 11 that the production of the $\mathrm{HHO}$ gas is the nearly the same percent of baking soda and vinegar but there is big difference with $\mathrm{NaOH}$.

It was noticed from Figure 12 that the exhaust gases temperature if $\mathrm{HHO}$ was used is always lower than the temperature if Gasoline was used, until (2500 RPM) they are the same temperature but the HHO temperature gets higher with higher speeds because of that the internal

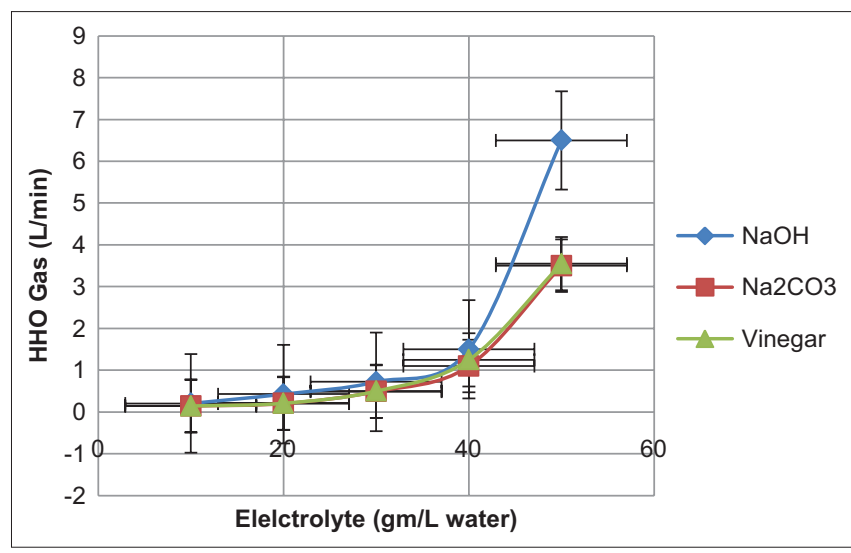

Figure 10: Curves represents the relationship between the electrolyte weight $(\mathrm{g})$ and hydroxy gas production

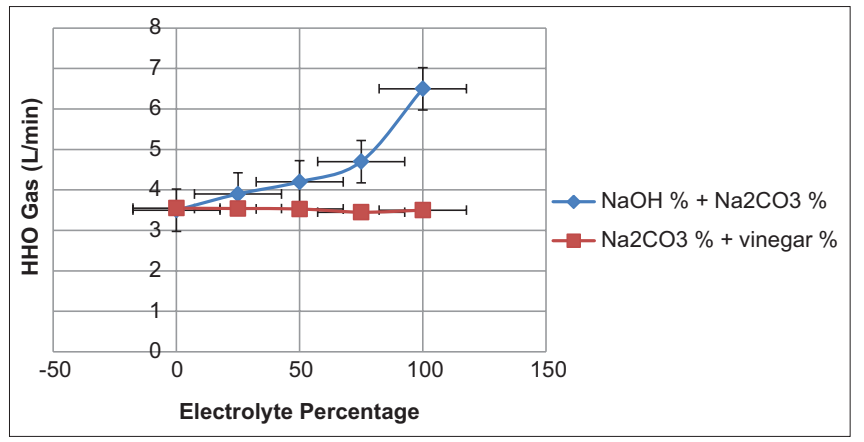

Figure 11: The relationship between electrolyte percentage with a constant weight of $(50-\mathrm{g})$, the variation is in the percentage of Sodium Hydroxide with baking soda, and baking soda with vinegar 


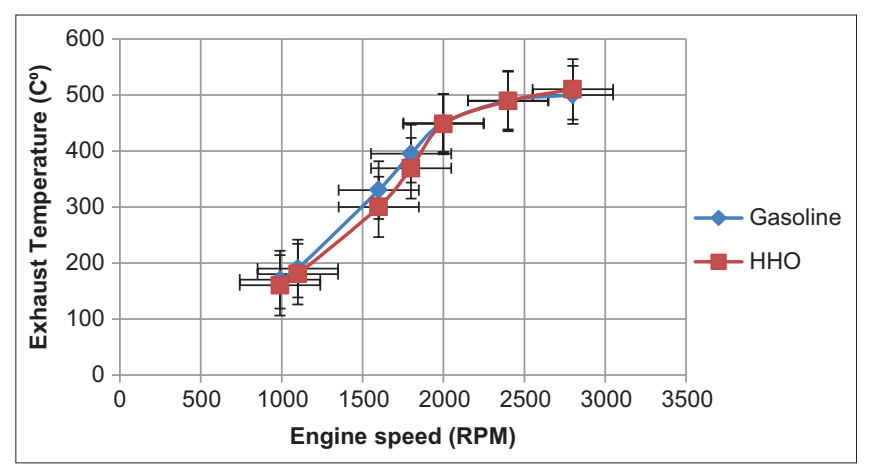

Figure 12: The relationship between the exhaust temperature and engine speed

energy stored in $\mathrm{H}_{2}$ is 3 times higher than in corresponding carbons. The efficiency of the generator was $80.24 \%$ by consuming near to $180 \mathrm{Watt}$ from the source and producing $4.2 \pm 0.1 \mathrm{~L} / \mathrm{min}$ of $\mathrm{H}_{2}$ gas out of $6.4 \pm 0.1 \mathrm{~L} / \mathrm{min}$ of $\mathrm{HHO}$ gas which has been gained from using $50 \mathrm{~g}$ of $\mathrm{NaOH}$ electrolyte.

\section{CONCLUSIONS}

The engine runs smoother with $\mathrm{HHO}$, this reduction in the temperature of the engine at lower speeds relative to gasoline from 990 to $2000 \mathrm{RPM}$ that is also responsible for enhancing the life of the engine since it is protected from unnecessary heating effects.

1. The use of $\mathrm{NaOH}$ solution in the $\mathrm{HHO}$ gas generator enhances the production efficiency of the gas while using baking soda and vinegar approximately has the same result in producing $\mathrm{HHO}$ gas

2. $\mathrm{NaOH}$ is the element of boosting the production of $\mathrm{HHO}$ gas when mixed with $\mathrm{Na}_{2} \mathrm{CO}_{3}$ while mixing the latter with vinegar does not affect enhancing the production of the gas

3. When $\mathrm{HHO}$ gas is produced from a source as $\mathrm{H}_{2} \mathrm{O}$, it can be confirmed that any emissions as $\left(\mathrm{NO}_{\mathrm{x}}, \mathrm{SO}_{\mathrm{x}}\right)$ and other environmentally harmful material would not be caused by the components of fuel used

4. The Fuel Cell which can be used is simple, easily constructed, and easily integrated with existing engines at a low cost

5. The exhaust temperatures at high speeds (20002800RPM) were nearly the same though the gasoline has higher heat value relative to $\mathrm{HHO}$ because of the high capability of storing internal energy of $\mathrm{H}_{2}$ more than corresponding carbon.

\section{REFERENCES}

ABDALLAH, M., SALEM, M., ZAAFARANY, I., FAWZY, A. \& FATTAH, A. A. 2017. Corrosion performance of stainless steel and nickel alloys in aqueous sodium hydroxide as revealed from cyclic voltammetry and potentiodynamic anodic polarization. Oriental Journal of Chemistry, 33, 2875.

APPLEBY, A. 1994. Fuel cell electrolytes: evolution, properties and future prospects. Journal of power sources, 49, 15-34.

BACON, F. T. 1969. Fuel cells, past, present and future. Electrochimica Acta, 14, 569-585.

BADWAL, S. P., FOGER, K., ZHENG, X. G. \& JAFFREY, D. 1999. Fuel cell interconnect device. Google Patents.

BARCLAY, F. 2002. Fundamental thermodynamics of fuel cell, engine, and combined heat and power system efficiencies. Proceedings of the Institution of Mechanical Engineers, Part A: Journal of Power and Energy, 216, 407-417.

BARRETO, L., MAKIHIRA, A. \& RIAHI, K. 2003. The hydrogen economy in the $21^{\text {st }}$ century: a sustainable development scenario. International Journal of Hydrogen Energy, 28, 267-284.

DUNN, S. 2002. Hydrogen futures: toward a sustainable energy system. International journal of hydrogen energy, 27, 235-264.

EL-KASSABY, M. M., ELDRAINY, Y. A., KHIDR, M. E. \& KHIDR, K. I. 2016. Effect of hydroxy (HHO) gas addition on gasoline engine performance and emissions. Alexandria Engineering Journal, $55,243-251$.

HOOGERS, G. 2002. Fuel cell technology handbook, CRC press.

ILHAK, M. I., TANGOZ, S., AKANSU, S. O. \& KAHRAMAN, N. 2019. Alternative Fuels for Internal Combustion Engines. The Future of Internal Combustion Engines. IntechOpen.

LARMINIE, J., DICKS, A. \& MCDONALD, M. S. 2003. Fuel cell systems explained, J. Wiley Chichester, UK.

MATLOOB, M. H. 2014. Zahdi date vinegar: Production and characterization. American Journal of Food Technology, 9, 231245.

MOMIRLAN, M. \& VEZIROGLU, T. 2002. Current status of hydrogen energy. Renewable and sustainable energy reviews, 6, 141-179.

SANTILLI, R. M. 2006. A new gaseous and combustible form of water. International Journal of Hydrogen Energy, 31, 1113-1128.

SCHULTE, I., HART, D. \& VAN DER VORST, R. 2004. Issues affecting the acceptance of hydrogen fuel. International Journal of Hydrogen Energy, 29, 677-685.

SHINNAR, R. 2003. The hydrogen economy, fuel cells, and electric cars. Technology in society, 25, 455-476.

SIERENS, R. \& ROSSEEL, E. Sequential injection of gaseous fuels. Proceedings of the Fifth International EAEC Congress, Strasbourg, June, Paper No SIA 9506A03, 1995. 10.

SIERENS, R. \& ROSSEEL, E. Variable composition hydrogen/natural gas mixtures for increased engine efficiency and decreased emissions. Proceedings of the ASME 1998 Spring Engine Technology Conference (ICED division), Fort Lauderdale, April 1998, paper 98-ICE-105. 1998. 